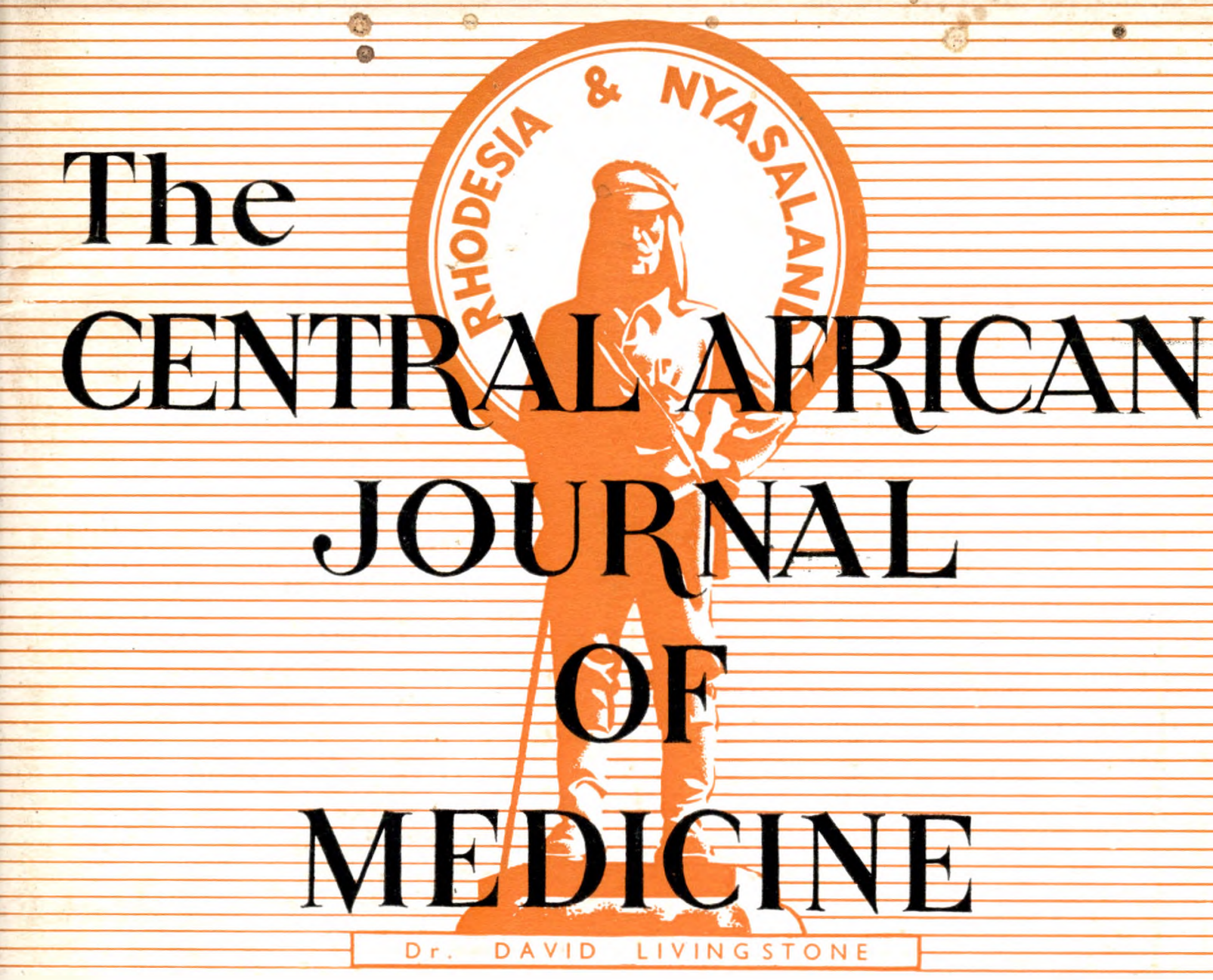




\section{Dietary Fat and Coronary Heart Disease}

BY

H. GORDON, B.sc., M.D. (Cape)

Clinical Research Bursar; from the Department of Medicine, University of Cape Town, and Groote Schuur Hospital and the C.S.I.R./U.C.T. Clinical Nutrition Research Unit.

The suggestion that dietary fats may play a part in the pathogenesis of coronary heart disease is not a new one, and its origins may be traced to biblical times. The diet of the ancient Egyptians, particularly that of the upper classes, was a rich one (Keller, 1956), and the Israelites in the desert often hankered after the fleshpots of Egypt (Numbers ii, 18). It will be recalled that in those days Pharoah often "hardened his heart." The Pharoah concerned is believed to have been Merneptah, and an examination of his mummy (Shattock, 1909) has revealed that he certainly hardened his arteries. His aorta showed marked arteriosclerosis, and similar changes, including intimal lesions, have been demonstrated in the mummies of a number of middle dynastic Egyptians (Ruffer, 1911). Was this the basis of the scriptural warning to the Israelites: "Thou shalt eat no manner of fat of ox, or of sheep, or of goat" (Leviticus vii, 23)?

In its modern guise the dietary fat theory can be stated as follows: the serum-cholesterol level depends largely on the amount of fat in the diet, and high serum-cholesterol levels are associated with a high incidence of coronary heart disease. According to this theory, the relationship between dietary fat, serum-cholesterol and coronary heart disease is a triangular one (Fig. 1). Most investigators are concerned with sides (a) and (b) of this triangle and, if these two sides are established, the relationship (c) of dietary fat and coronary heart disease will be substantiated. Side (a), which relates the serumcholesterol level to the dietary fat, has been thoroughly investigated, and although the relationship is not a simple one, it may be regarded as established. Side (b), indicating the importance of the-serum-cholesterol level in the pathogenesis of coronary heart disease, is supported by a great deal of indirect evidence, but at present cannot be taken as finally proven.

In this paper some aspects of this triangular relationship will be reviewed and some practical consequences will be discussed.

\section{The Relation of Serum-Cholesterqu LeVels to THE DEVelopMent OF Coronary Heart Disease}

The association of high serum-cholesterol levels with atherosclerosis has been noted since the early experiments of Anitschkow and Chalatow (1913), who produced hypercholesterolaemia and atheromatosis in rabbits by feeding large amounts of cholesterol. Since then, similar lesions have been produced in rats, dogs, chickens, monkeys and guinea pigs-all by procedures which elevate the serum-cholesterol level. The experimental lesions may be reversed by reducing the hypercholesterolaemia. It must be noted that the diets used in these experiments are highly artificial and that hypercholesterolaemia and atherosclerosis do not occur in these animals in the natural state. It is also to be noted that, although the experimental atheromatosis is often gross, myocardial infarction is extremely rare in these animals; recently, however, Hartroft and Thomas (1957) have been able to produce infarcts in rats by feeding them

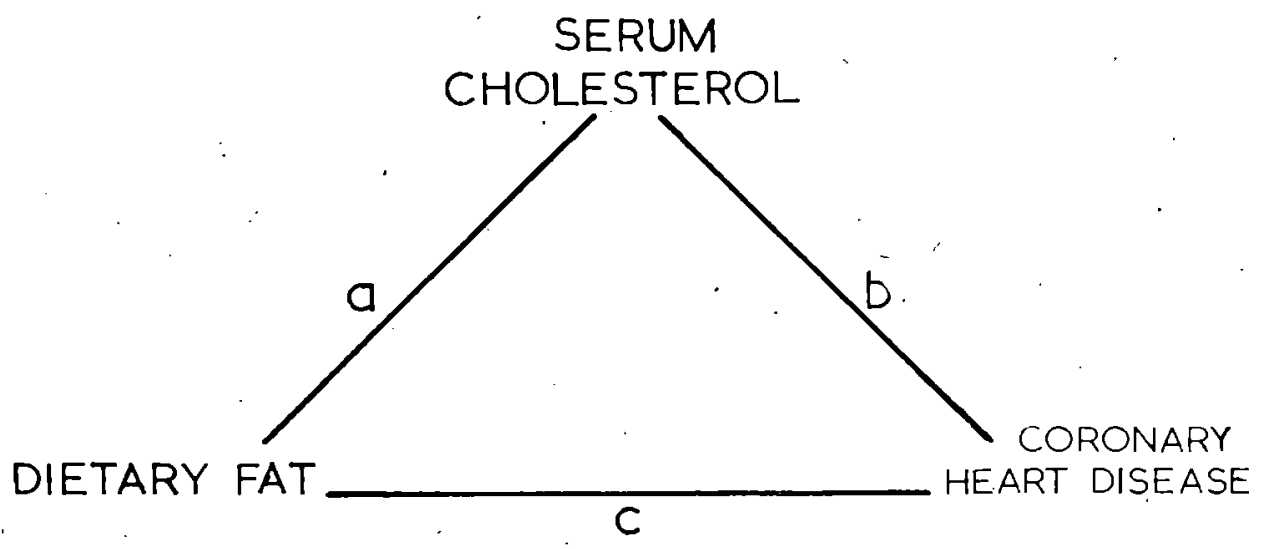

Fig. 1.

Page Four Hundred and Twenty-Four 
with a complex diet of cholesterol, lard or butter, thiouracil and cholic acid.

Biochemically, the similarity of the serum lipids and the atherosclerotic plaques is striking. Thus Hirsch and Weinhouse (1943) showed that the proportionate distribution of lipids in human plasma and in the intima is nearly identical; similarly in the early atheromatous lesions the total lipid is increased, but the distribution of its various fractions still resembles that of the plasma very closely.

The relationship is further strengthened by the high incidence of atherosclerosis in diseases in which high serum-cholesterol levels occur. These diseases include diabetes mellitus, myxoedema, nephrosis, obstructive jaundice, primary hypercholesterolaemia and primary hyperlipaemia (Katz and Stamler, 1953). Atherosclerosis, often with severe coronary heart disease, may occur even in very young people with these diseases. Recently attention has been drawn to cases of progeria in which the serum-cholesterol is elevated and in which advanced atherosclerosis may sometimes occur in children only three years old (Keay et al., 1955).

Finally, there is the oft-repeated observation that, in general, men with clinical coronary heart disease have higher serum-cholesterol levels than chinically healthy men. For example, Gertler and White (1954) studied two groups of men under 40 years of age. The mean serumcholesterol level in the 97 men with coronary heart disease was $286 \mathrm{mg}$. per cent.; in the age-matched controls the mean level was 242 mg. per cent. In these retrospective studies the control groups are open to criticism; they are "normal" only in the immediate clinical sense and many of them may have severe but sub-clinical atherosclerosis. Thus Morris (1956) has pointed out that in England over 60 per cent. of men aged 60 to 64 years have material amounts of coronary atherosclerosis, whereas only 5 per cent. have clinical coronary heart disease. For this reason it is possible that prospective studies may provide a more useful. correlation. Preliminary observations in two such surveys have been reported (Gofman et al., 1956; Dawber et al., 1957) and in both, men with initially elevated serum-cholesterol levels were found to develop coronary heart disease more readily than those who initial serumcholesterol levels were "average" or less. For example, at Framingham, in the United States of America, in a four-year study of 898 apparently healthy men, the rate of development of overt coronary heart disease was 122 per 1,000 for those with initial serum-cholesterol levels over $260 \mathrm{mg}$. per cent.; in those whose initial levels were less than $225 \mathrm{mg}$. per cent., the rate was 40 per 1,000 (Dawber et al., 1957).

\section{Dietary Fat and Serum-Cholesterol Levels}

The animal experiments of Anitschkow and others suggested that the serum-cholesterol level is largely dependent on the dietary cholesterol intake. It is now clear, however, that in human beings the cholesterol of ordinary diets. has a negligible effect on the serum-cholesterol level (Keys et al., 1956). 'On the other hand, there is considerable epidemiological evidence of a close association between man's dietary fat intake and his serum-cholesterol level. Some examples of this evidence will be described briefly.

1. Inter-Racial Comparisons.-In the Cape Peninsula three races live under identical geographic conditions: the European, the Cape Coloured and the Bantu; the latter are mainly migrant labourers from the Transkei. Agematched groups of adult men of each race were investigated by a team directed by Professor J. F. Brock (Bronte-Stewart et al., 1955). Some of the relevant data are shown in Table I.

It will be seen that of all age groups, the Bantu, who represent the lowest socio-economic strata, have the lowest fat consumption and the lowest serum-cholesterol levels. The Europeans belong to the upper socio-economic class; they consume a diet rich in fat and have the highest serum-cholesterol levels. The Cape Coloured folk occupy an intermediate socio-economic position, and both their fat consumption and their serum-cholesterol levels are intermediate between

Table I

\begin{tabular}{|c|c|c|c|c|c|c|c|c|}
\hline \multirow{2}{*}{\multicolumn{2}{|c|}{ Race }} & \multirow{2}{*}{\multicolumn{2}{|c|}{ 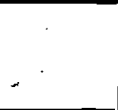 }} & \multirow{2}{*}{$\begin{array}{c}\text { Number of } \\
\text { Men }\end{array}$} & \multirow{2}{*}{$\begin{array}{l}\text { Dietary Fat } \\
\text { (Per Cent. of } \\
\text { all Calories })\end{array}$} & \multicolumn{3}{|c|}{ Setum-Cholesterol (mg. per cent.) } \\
\hline & & & & & & $20-29$ Years & 30-39 Years & 40-49 Years \\
\hline Bantu & $\ldots . .$. & $\ldots \ldots$ & $\ldots . .$. & 183 & 17 & 154.8 & 168.8 & 168.5 \\
\hline Coloured & $\cdots . .$. & $\ldots .$. & $\ldots$. & 102 & 25 & 159.6 & 194.1 & 195.0 \\
\hline European & $\ldots . .$. & ....... & $\ldots . . .$. & 129 & $35-40$ & 203.3 & 223.4 & 241.8 \\
\hline
\end{tabular}


those of the Bantu and the European. Additional significance is given to these data by a companion study of the incidence of myocardial infarction at Groote Schuur Hospital. In this study, Vogelpoel and Schrire (1955) studied 550 consecutive electrocardiographs showing the classical cardiac infarction pattern. The incidence of this pattern per 100 electrocardiographs was: European, 13.5; Coloured, 6.8; and Bantu, 0.9 . Thus, the interracial differences which exist with respect to dietary fat intake and the serumcholesterol levels are paralleled by the differences in the incidence of cardiac infarction.

2. Intra-Racial Comparisons.-Similar trends have been noted in intra-racial surveys. The most recent of these have been carried out among the Japanese under the direction of Dr. Ancel Keys (1957). The findings are summarised in Table II.

It will be noticed that increasing "Westernisation" of the Japanese increases the fat content of their diet, with a parallel increase in the serum-cholesterol level. The incidence of coron-
McVay, 1956; Thomas et al., 1957). Further north, however, the death rate of middle-aged, urbanised Negro males is as high or higher than that of the whites (Stamler, 1956).

Low Fat Diets.-In addition to these epidemiological studies, clinical experience has indicated that the therapeutic use of low fat diets (e.g., the "rice diet" for hypertension) may produce a fall in the serum-cholesterol level (Starke, 1950; Mellinkoff et al., 1950). . In clinical trials, Keys (1952) has reduced the serum-cholesterol to 80 per cent. of its control level by changing the fat content of the diet from 150 g. to $15 \mathrm{~g}$. per day.

\section{The Effect of Different Fats on the Serum-Cholosterol LeVel}

Not all the epidemiological evidence conforms to the general pattern of "high dietary fathigh serum-cholesterol level," and a number of significant exceptions must be considered.

1. Vegetarians often consume large amounts of fat from vegetable sources, yet their serum-

Table II

\begin{tabular}{|c|c|c|c|c|c|c|c|c|}
\hline \multicolumn{7}{|c|}{ Japanese Men (Age-Matched) } & $\begin{array}{c}\text { Dietary Fat } \\
\text { Per Cent. of All Calories }\end{array}$ & \multirow{2}{*}{$\begin{array}{c}\begin{array}{c}\text { Mean Serum-Cholesterol } \\
\text { (mg. Per Cent. })\end{array} \\
150\end{array}$} \\
\hline In & Kyushu, & Japan & 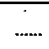 & $\ldots$ & $\ldots$ & $\ldots \ldots$ & 10 & \\
\hline In & Hawaii & $\ldots \ldots$ & $\therefore \ldots$ & $\ldots$ & $\ldots$ & $\ldots \ldots$ & 22 & 220 \\
\hline In & Los Ang & eles & $\ldots . .$. & $\ldots$ & $\ldots$ & $\ldots \ldots$ & 38 & 245 \\
\hline
\end{tabular}

ary heart disease follows the same "trend: that of the Los Angeles Japanese is about twice that of the Hawaiian, which in turn is about five times that of the Kyushu.

3. Bantu and American Negroes.-The effect of "Westernisation" is of particular interest to us in Africa. In a survey of the literature relating to diet, serum-cholesterol and coronary heart disease in the indigenous populations of the southern part of the African continent (Brock and Gordon, 1958), the general pattern of low dietary fat, low serum-cholesterol and low incidence of coronary heart disease was found consistently. In the United States of America, the American Negro presents quite a different picture. His way of life is similar to that of his white compatriots and he develops coronary heart disease much more commonly than the Bantu in Africa. 'In the southern United States, where the socio-economic status of the rural Negro is relatively low, the incidence of coronary heart disease is substantially lower than that of the White (Keil and cholesterol levels are lower than those of the general population (Donath et al., 1953; Hardinge and Stare, 1954). In Yugoslavia, Brozek et al. (1957) compared two population groups. Farmers living on the mainland in the north-east consume a diet which provides 90 per cent. of its fat from animal sources; they have a mean serum-cholesterol level (age-adjusted to 40 years) of $239 \mathrm{mg}$. per cent. A similar group of men living on islands off the Adriatic coast derive over 90 per cent. of their fat from olive oil; their mean serum-cholesterol level (similarly adjusted) is $201 \mathrm{mg}$. per cent.

2. Eskimos most of the year live on a carnivorous diet consisting largely of seal, whale and fish. Their diet is rich in fat (Sinclair, 1954), but in general they have low serum-cholesterol levels. in!

Because of these discrepancies it was necessary to conduct feeding experiments in which the effects of different fats on the serum-cholesterol level could be studied. Many such. experiments 
have been conducted in various parts of the world, and the results may be summarised as follows (Brock and Gordon, 1957):

(1) Fats differ in their effect on the serum-cholesterol; some raise its level, some lower it and some have no effect.

(2) The fats which lower the serum-cholesterol level are generally from vegetable sources (e.g., sunflower seed, corn, soyabean) or of marine origin (e.g., - pilchard, seal, sardine). These fats are generally liquid at room temperature (i.e., they are oils) and contain large amounts of "essential fatty acids" (linoleic, linolenic, arachidonic and hexaenoic acids). These oils are highly unsaturated, as indicated by their iodine values, which are generally over 100 .

(3) Not all vegetable fats behave similarly. Some less unsaturated oils (iodine value 80-90), with lesser amounts of essential fatty acids, may not depress the serum-cholesterol significantly; olive oil and peanut oil represent this category. Some yegetable fats behave like animal fats and raise the serum-cholesterol level; coconut fat (iodine value 9) is typical of this group.

(4) When liquid vegetable oils are artificially hardened ("hydrogenated"), as in the manufac. ture of margarine and certain cooking fats, they may lose their cholesterol-lowering properties and behave like animal fats. Like animal fats (lard, butter, dripping), they have low iodine values and practically no essential fatty acids, and they sometimes raise the serum-cholesterol of the human subjects to whom they are given.

(5) When highly unsaturated and saturated fats are fed together, the former may partly or completely reverse the cholesterogenic effect of the latter.

(6) The effects of the various fats are independent of changes in body weight and calorie intake and of the protein and vitamin content of the diet.

In Table III the commonly used fats are tabulated, together with their approximate iodine values.

It has yet to be established which characteristic of a fat determines its lowering effect on the serum-cholesterol. From Table III it seems likely that the degree of unsaturation of the fat is of prime importance (Ahrens et al., 1957). It has been suggested, however, that the activity of a fat is more precisely determined by its content of essential fatty acids (Sinclair, 1956; Kinsell et al., 1956). Others (Beveridge et al., 1957) claim that the fatty acids are of less importance and that it is a factor in. the unsaponifiable fraction (e.g., sitosterol) which is important. Further work will be required to elucidate this point.

The mechanism whereby these unsaturated fats lower the serum-cholesterol level is also of some significance. Bo these fats interfere with the synthesis of cholesterol or do they facilitate its excretion from the body? Or may they actually do harm by encouraging the deposition of cholesterol from the blood stream into the tissues, including the arterial wall? In an attempt to answer these questions we have conducted a number of metabolic studies in which the effects of a fat-free diet, hydrogenated coconut fat and sunflower seed oil, "have been compared (Gordon et al., 1.957). The results of these studies indicate that when the serumcholesterol level is lowered by sunflower seed oil there is a substantial increase in the faecal excretion of the end products of cholesterol metabolism-particularly the bile acids. Thus, sunflower seed oil apparently promotes the catabolism of cholesterol to bile acids and hence its excretion from the body.

Clinical Trials.-The experiments described above were generally short-term trials done under artificial conditions, i.e., in metabolic wards, using unnatural diets containing large loads of the test fats. The next step was to

\section{Table III}

\begin{tabular}{|c|c|c|c|c|c|c|c|}
\hline 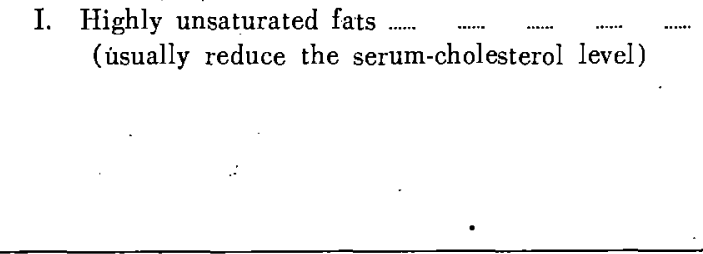 & 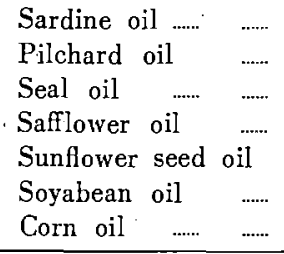 & 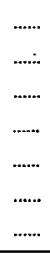 & 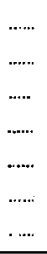 & $\begin{array}{c}\text { Iodin } \\
\quad " \\
" \\
" \\
" \\
" \\
"\end{array}$ & $\begin{array}{c}\text { value } \\
" \\
" \\
" \\
" \\
" \\
"\end{array}$ & 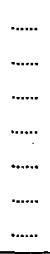 & $\begin{array}{l}188 \\
180 \\
166 \\
145 \\
135 \\
135 \\
120\end{array}$ \\
\hline $\begin{array}{l}\text { II. Moderately unsaturated fats .................................... } \\
\text { (little or no effect on the serum-cholesterol level) }\end{array}$ & $\begin{array}{l}\text { Cotton seed oil } \\
\text { Groundnut oil } \\
\text { Olive oil }\end{array}$ & $\ldots .$. & 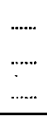 & $"$ & " & $\cdots$ & $\begin{array}{r}105 \\
88 \\
88 \\
\end{array}$ \\
\hline $\begin{array}{l}\text { III. Saturated fats } \\
\text { (usually elevate the serum-cholesterol level) }\end{array}$ & $\begin{array}{l}\text { Lard } \ldots . . . \\
\text { Dripping } \\
\text { Butter } \\
\text { Cocoanut oil }\end{array}$ & 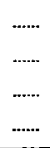 & 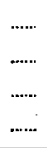 & $\begin{array}{l}" \\
" \\
"\end{array}$ & $\begin{array}{l}" \\
", \\
",\end{array}$ & 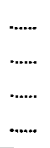 & $\begin{array}{r}55 \\
45 \\
40 \\
9\end{array}$ \\
\hline
\end{tabular}


study the effect of the fats under normal conditions. For this purpose we have enlisted the aid of a number of European business men. These men (some of whom have coronary heart disease) continue with their customary activity and diets throughout the trial. There is an initial control period of about two to three months, during which a weekly estimation of their serum-cholesterol levels is made. They are then given about $50 \mathrm{~g}$. of a highly unsaturated oil daily as a supplement to their regular diet; this is taken for about six months, during which weekly serum-cholesterol estimations are continued. A second control period of two to three months follows after stopping the oil. The results in the first ten men to complete this trial are shown in Table IV (Gordon and Brock, 1958). All but one of the men had a significant fall in his serum-cholesterol level while on the oil, the mean fall for the group being $34 \mathrm{mg}$. per cent.

Throughout this trial a close watch was kept on the subjects' weight. Although most of the subjects gained weight while on the oil supple- the development or progression of atherosclerosis. Within the limitations of present experience, however, serum-cholesterol lowering regimes may be recommended with some justification to two groups of individuals, viz.:

(1) Those with primary hypercholesterolaemia or primary hyperlipaemia, i.e., two relatively rare inborn errors of lipid metabolism.

(2) Men with coronary heart disease or those with a strong family history of the disease, who have high serum-cholesterol levels. It is difficult to define "high serum-cholesterol levels," but it is tentatively suggested that levels over $275 \mathrm{mg}$. per cent. should be regarded as undesirable. An individual's level may, however, show considerable spontaneous fluctuation from week to week; hence more than one reading should be made before finally assessing the state of his serum-cholesterol.

The evidence at present does not provide grounds for a recommendation to the population as a whole to make any major changes in their eating habits. Re-affirmation of the principle of moderation in all dietetic matters and a reminder to actively avoid the development of obesity in middle age are all that is required as general advice to one's patients.

Table IV

One Year Study of the Serum-Cholesterol Variations in Ten Men

\begin{tabular}{|c|c|c|c|c|c|}
\hline & \multirow{2}{*}{$\begin{array}{c}\begin{array}{c}\text { First Control } \\
\text { Period } \\
(15 \text { WEelts })\end{array} \\
\begin{array}{c}\text { Serum- } \\
\text { Cholesterol }\end{array}\end{array}$} & \multicolumn{2}{|c|}{$\begin{array}{l}\text { Oil Supplement } \\
\quad(23 \text { Weeks })\end{array}$} & \multicolumn{2}{|c|}{$\begin{array}{c}\text { Second Control Period } \\
(14 \text { Weeks })\end{array}$} \\
\hline & & $\begin{array}{c}\text { Serum- } \\
\text { Cholesterol }\end{array}$ & Difference & $\begin{array}{l}\text { Serum- } \\
\text { Cholesterol }\end{array}$ & Difference \\
\hline Mean (mg. per cent.) & 247 & 213 & -34 & 246 & +33 \\
\hline Range (mg. per cent.) & 215 to 340 & 186 to 253 & -2 to -87 & 224 to 322 & +6 to +69 \\
\hline
\end{tabular}

ments, an occasional man lost weight; this suggests that "there may have been an unconscious tendency to restrict his food intake while consuming the oil. No regular correlation has been detected between gain or loss of body weight and the fall in serum-cholesterol level (Fig. 2).

\section{INDICATIONS FOR LOWERING THE Serum-Cholesterol Level}

Our studies on the effect of different fats on the serum-cholesterol level are not yet complete. The evidence thus far clearly indicates that the serum-cholesterol level can be lowered by dietary modification and that it is possible to maintain this reduction for extended periods. At present it is not possible precisely to define the indications for reducing the serum-cholesterol level. It has yet to be shown by direct clinical trial in human beings that such reduction will inhibit
Practical Diets for Reducing the Serum-Cholesterol Level.

Hitherto the diets recommended for lowering the serum-cholesterol were strictly low in fat content. Such diets allow for little variation in the food intake and are difficult to prepare in palatable and attractive form. They rapidly become irksome to the patient, and their continued use may lead to gastrointestinal upset (Page, 1952). and to irritability and mental depression (van Handel et al., 1957). Unless the fat restriction is sedulously enforced, a substantial fall in the serum-cholesterol level cannot be anticipated (Hatch et al., 1955).

The introduction of unsaturated fats into the regime improves the patient's lot considerably. It becomes possible now to make only a moderate reduction in the intake of saturated fats while 
reasonable quantities of unsaturated fats are allowed. Detailed accounts of such diets cannot be given here, but a few generalisations will be made.

The saturated fat intake may be reduced by eating less meat, particularly beef, mutton and pork. Breast of chicken, young chicken, liver, kidneys, tripe and lean veal contain little fat and need not be restricted. Dairy products (eggs, milk, cheese, cream, ice cream and butter, but not skimmed milk derivatives) are rich in saturated fats and should be restricted to a minimum. On the other hand, fish in all its forms may be eaten liberally and the use of natural vegetable oils for frying, roasting, salad dressings and pastries is to be encouraged. The position of hydrogenated fats (margarines and shortenings) is not yet clear; some tend to raise the serum-cholesterol level and they should probably be avoided.

It will be seen that with a little gastronomic enterprise meals to satisfy most palates can be prepared. Fresh fruit, cereals (with skimmed milk) and kippers make as good a breakfast as the standard "bacon and eggs." Plenty of scope for tasty dishes rich in marine and vegetable oils will be found by those who consult books on Mediterranean and Eastern cooking. Interesting desserts can be made using fruit jellies, instead of "pie a la mode," and a taste for skimmed milk in tea or coffee is soon acquired. The interests of commercial food technologists have already been aroused; thus, in Sweden, Malmross and Wigand (1957) have successfully used diets. containing large amounts of cheese and ice cream made from milk which had been defatted and then reconstituted with corn oil.

Enthusiasm for diets rich in unsaturated fats must be tempered by three considerations. Firstly, such diets are rich in calories, and the importance of avoiding obesity should not be overlooked in the management of coronary heart disease. Secondly, these diets are only aimed at reducing the serum-cholesterol level and they ignore the possibility of adversely affecting other pathogenic mechanisms. In this connection it must be recalled that a strong (but not unanimous) body of opinion favours the view that dietary fats promote the development of coronary heart disease by encouraging thrombogenesis (e.g., Fullerton, 1956, but cf. Merskey and Nossel, 1957) and there is no convincing evidence of a differential effect of saturated and unsaturated fats on the coagulability of the blood (Keys et al., 1957). Others believe that dietary fats may inhibit the fibrinolytic activity of the plasms; this inhibitary property is apparently not possessed by unsaturated fats (Greig, 1957).

The final consideration is a psychological one. Patients should not be allowed to become obsessed with the need for meticulous attention to culinary detail, and housewives should be protected from the acute anxiety states engendered by over-consciencious attempts at implementing their husbands' dietary regime. Too many cardiac patients become blood pressure or prothrombin neurotics. It would be most unfortunate if "cholesterolphobia" were to be

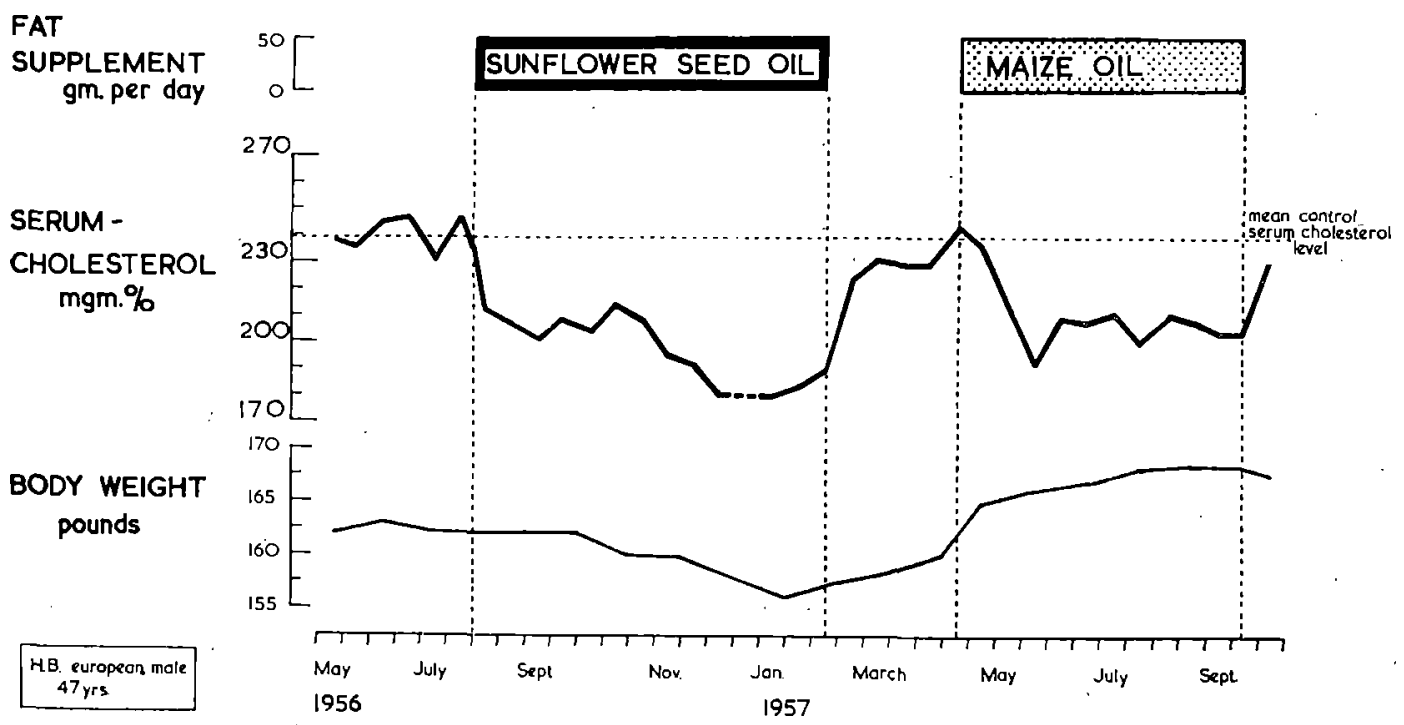

Fig. 2. 
added to the iatrogenic complications of coronary heart disease.

\section{Other Atherogenic Factors}

We are accustomed to taking a unitarian view. of the aetiology of disease. Thus, pneumonia is due to the pneumococcus, scurvy is due to ascorbic acid deficiency and thyrotoxicosis is the result of an over-active thyroid gland. For several common diseases, however, a single causal agent has not yet been found and it is likely that the elucidation of their aetiology will necessitate a departure from the unitarian principle. This most certainly applies to a complicated disease like atherosclerosis, in which so many pathogenic processes are concerned.

These processes include, firstly, the structural and metabolic changes in the vessel wall which localise the lesions. Secondly, there are the general disturbances in lipid transport and metabolism; these are responsible for the development of the atheromatous plaques either through the mechanism of atherogenesis or of primary thrombogenesis. Both the local and general disturbances are in turn dependent on a host of endogenous and exogenous factors. Among the endogenous factors, the problems of hereditary and endocrine influences have to be considered. That coronary heart disease "runs in families" is common experience; to what extent this is due to genetic factors and to what extent "family habits" play a part is not yet clear. The particular susceptibility of individuals with stocky, slightly obese body habitus may be explained on genetic grounds, and a similar influence may play a part in determining the interracial incidence of the disease. The importance of the endocrine influence is illustrated by resistence of white women to the disease during their reproductive years; whether "feminisation" due to liver dysfunction in the African similarly protects him from coronary heart disease is yet to be established.

Potential exogenous influences are no less numerous and many remain to be evaluated. The nebulous entity of "stress and strain" is often invoked as a cause for the high incidence of the disease in otherwise privileged populations; according to this theory, the African is not subject to these influences and is therefore immune to the disease. The opinions of practitioners familiar with the vicissitudes of the Africans' existence may be at variance with this hypothesis. The indolent life of the white man as compared with the physical vigour of the African is also blamed by some, while others would add cigarette smoking to the list of exogenous evils.

Of all the environmental factors, however, none has received as much attention as the diet. Most dietetic constituents have to be considered in relation to this problem, and thus far most of the evidence testifies to the importance of the dietary fat. It is almost certainly not the only factor and it may not even be the most important, but it is at present the one which is most susceptible to modification. Whether such modification will eventually reduce the ravages of atherosclerosis will only be known after patient and meticulously controlled clinical trials.

\section{Summary}

(1) The role of the dietary fat in regulating the serum-cholesterol level is now established. In this respect the quality of the dietary fat is more important than its quantity.

(2) The evidence for a relationship between the serum-cholesterol level and the development of coronary heart disease is very strong, but it is not complete.

(3) Nevertheless, under certain circumstances it may be justified to recommend cholesterolreducing diets. Some practical aspects of such diets are discussed.

(4) It is stressed that the dietary fat is only one of many factors which may be concerned in the pathogenesis of coronary heart disease.

\section{Acknowledgment}

I should like to thank Professor J. F. Brock (Director of the C.S.I.R./U.C.T. Clinical Nutrition Research Unit), who has guided me in formulating many of the ideas expressed in this paper.

\section{REFERENCES}

Ahrens, E. H., Hirsch, J., Insull, W., Tsaltas, T. T., Blomstrand, R. \& Peterson, M. L. (1957). Lancet, i, 943 .

Anitschkow, N. \& Chalatow, S. (1913). Central bl. f. allg. Path, u. path. Anat., 24, 1.

Beveridge, J. M. R., Connel, W. F. \& Mayer, G. A. (1957). Fed. Proc., 16, 11.

Brock, J. F. \& Gordon, H. (1957). S. Afr. med. J., 31,663 .

- (1958). In the press.

Bron'te-Stewart, B., Keys, A. \& Brock, J. F. (1955). Lancet, ii, 1103.

Brozek, J., Buzina, R. \& Mrkic, F. (1957). Amer. J. Clin. Nutrit., 5, 279.

Dawber, T. R., Moore, F. E. \& ManN, G. V. (1957). Amer. J. Pub. Health, 47, 22. 
Donath, W. F., Fischer, I. A., van der Meulen van Eysbergen, H. C. \& DE WiJN, J. F. (1953). Voeding, 14, 153.

Fullerton, H. W. (1956). Proc. Nutrit. Soc., 15, 66.

Gertler, M. M. \& White, P. D. (1954). "Coronary Heart Disease in Young Adults: $A$ Multidisciplinary Study, p. 98. Cambridge, Mass. Harvard University Press.

Gofman, J. W. \& Others (1956). Circulation, 14, 691. Gordon, H. \& Brock, J. F. (1958). S. Afr. med. J., $32,397$.

$\longrightarrow$ Lancet, ii, 1299 .

Greig, H. B. W. (1956). Ibid., ii, 16.

Hardinge, M. G. \& Stare, F. J. (1954). Amer. J. Clin. Nutrit., 2, 83.

Hartfoft, W. S. \& Thomas, W. A. (1957). J. Amer. med. Assoc., 164, 1899.

Hatch, F. T., Abell, L. L. \& Kendall, F. E. (1955). Amer. J. Med., 19, 48.

Hursch, E. F. \& Weinhouse, S. (1943). Physiol. Rev., $23,185$.

KATZ, L. N. \& StamLen, J. (1953). Experimental Atherosclerosis. Springfield, Ill. C. C. Thomas.

Keay, A. J., Oliver, M. F. \& Boyd, G. S. (1955). Arch. Dis. Childh., 30, 410.

KEIL, P. G. \& McVAY, L. V. (1956). Circulation, 13, 712 .

Keller, W. (1956). The Bible as History, p. 120. London. Hodder \& Stoughton.
KeYs, A. (1952). Circulation, 5, 115. (1957). J. Amer. med. Assoc., 164, 1912. Anderson, J. 'T., Mickelsen, O., Adelson, S. F. \& Fidanza, F. (1956). J. Nutrit., 59, 39.

, Buzina, R., Grande, F. \& Anderson, J. T. (1957). Circulation, 15, 274.

Kinsell, L. W., Friskey, R. W., Michaels, G. D. and Brown, F. D. (1956). Amer. J. Clin. Nutrit., 4, 285.

Malmros, H. \& Wigand, G. (1957). Lancet, ii, 1.

Mellinkoff, S. M., Machella, T. E. \& Reinhold, J. G. (1950). Amer. J. med. Sci., 220, 203.

Merskey,. C. \& Nossel, H. (1957). Lancet, i, 806.

Morris, J. (1956) in KEYS, A. \& WhITE, P. D. World Trends in Cardiology, Vol. 1, Cardiovascular Epidemiology. Chap. 6, p. 42. New. York. HoeberHarper.

Page, I. (1952). Med. Clin. N. Amer. January, p. 195. Ruffer, M. A. (1911). J. Path. Bact., 15, 453.

Shatтock, S. G. (1909). Lancet, i, 319.

Sinclair, H. M. (1954). Proc. Nutrit. Soc, 12, 69. (1956). Lancet, i, 387.

Stamler, J. (1956). Nebraska State med. J., 41, 75.

Starke, H. (1950). Amer., J. Med., 9, 494.

Thomas, W. A., Blache, J. O. \& Lee, K, T. (1957). Arch. Int. Med., 100, 423.

van Handel, E., Neumann, H. \& Bloem, Th. (1957). Lancet, i, 245.

Vogelpoel, L. \& Schrire, V. (1955). Ibid., ii, 1108. 


\section{(c) (1) (9)}

This work is licensed under a

Creative Commons

Attribution - NonCommercial - NoDerivs 3.0 License.

To view a copy of the license please see:

http://creativecommons.ora/licenses/bv-nc-nd/3.0/ 